\title{
Effects of Antheridiol on Growth, Branching and Electrical Currents of Hyphae of Achlya ambisexualis
}

\author{
By NEIL A. R. GOW AND GRAHAM W. GOODAY* \\ Department of Genetics and Microbiology, University of Aberdeen, Marischal College, \\ Aberdeen AB9 $1 A S, U K$
}

(Received 1 June 1987; revised 11 August 1987)

\begin{abstract}
Treatment of male hyphae of the water mould Achlya ambisexualis with the female sex pheromone, antheridiol, caused them to stop extending. This response was accompanied by a marked decline in the characteristic inward current just behind the hyphal apex. After a hypha had stopped, a site of inward current developed some way behind the apex. Then an antheridial branch developed at this site. These responses only occurred in the absence of nutrients; in the presence of nutrients the hyphal extension rate and current pattern were unaffected by the addition of antheridiol.
\end{abstract}

\section{INTRODUCTION}

Female hyphae of the oomycete water moulds of the genus Achlya produce a sterol sex pheromone, antheridiol (McMorris, 1978). This causes male hyphae to show a series of responses: characteristic antheridial branching, chemotropic attraction of these branches and their development as antheridia with accompanying meiosis (Barksdale, 1963; Barksdale et al., 1974). Biochemical responses include an increase in cellulase activity (Thomas \& Mullins, 1969), an induced metabolism of antheridiol (Musgrave \& Nieuwenhuis, 1975), the synthesis of the male pheromone, oogoniol (McMorris, 1978), a marked enchancement of synthesis of protein, rRNA and mRNA, of histone acetylation, and of transcription in vitro (Silver \& Horgen, 1974; Timberlake, 1976) and changes in the pattern of secreted proteins (Brunt \& Silver, 1986). The hyphae of Achyla recently have proved amenable to studies of bioelectricity, and currents produced by growing and vegetatively branching hyphae and by developing sporangia have been reported (Kropf, 1986; Kropf et al., 1983, 1984; Armbruster \& Weisenseel, 1984; Gow et al., 1984, Gow, 1984). It is clear that vegetatively growing hyphae generate ion currents that enter their apices and exit sub-apically, and that sub-apical vegetative branching is associated with the formation of a localized inward-moving current (Kropf et al., 1983). Here we report on the effect of antheridiol on extension growth, branching and current pattern, and the effect of nutrients on these responses.

\section{METHODS}

Fungus growth and conditions. Achlya ambisexualis, male, strain E87 was kindly supplied by Professor T. C. McMorris. It was grown on agar plates of the nutrient mating medium of Barksdale et al. (1974), modified by substituting casein hydrolysate for Edamin and sodium glycerophosphate for calcium glycerophosphate, with the addition of $60 \mathrm{mg} \mathrm{CaCl} 2.6 \mathrm{H}_{2} \mathrm{O} \mathrm{I}^{-1}$. All growth and experiments were at $25^{\circ} \mathrm{C}$.

For investigating the effects of antheridiol, the fungus was grown from a central hyphal inoculum for $3 \mathrm{~d}$ on agar plates. From each plate, two agar blocks, $2 \times 0.5 \mathrm{~cm}$, were excised from the younger part of the culture. Each was left for $30 \mathrm{~min}$, stuck in a plastic Petri dish with silicone dental cement and just submerged either in artificial pond water $\left(0.1 \mathrm{mM}-\mathrm{KCl}, 0.1 \mathrm{mM}-\mathrm{CaCl}_{2}, 1.0 \mathrm{~mm}-\mathrm{NaCl}, \mathrm{pH} 6.0\right)$ or in the nutrient mating medium. The hyphae that grew out from the top surface were viewed with an inverted microscope. Large hyphae that were vigorously growing straight out from the block were chosen for further examination. 


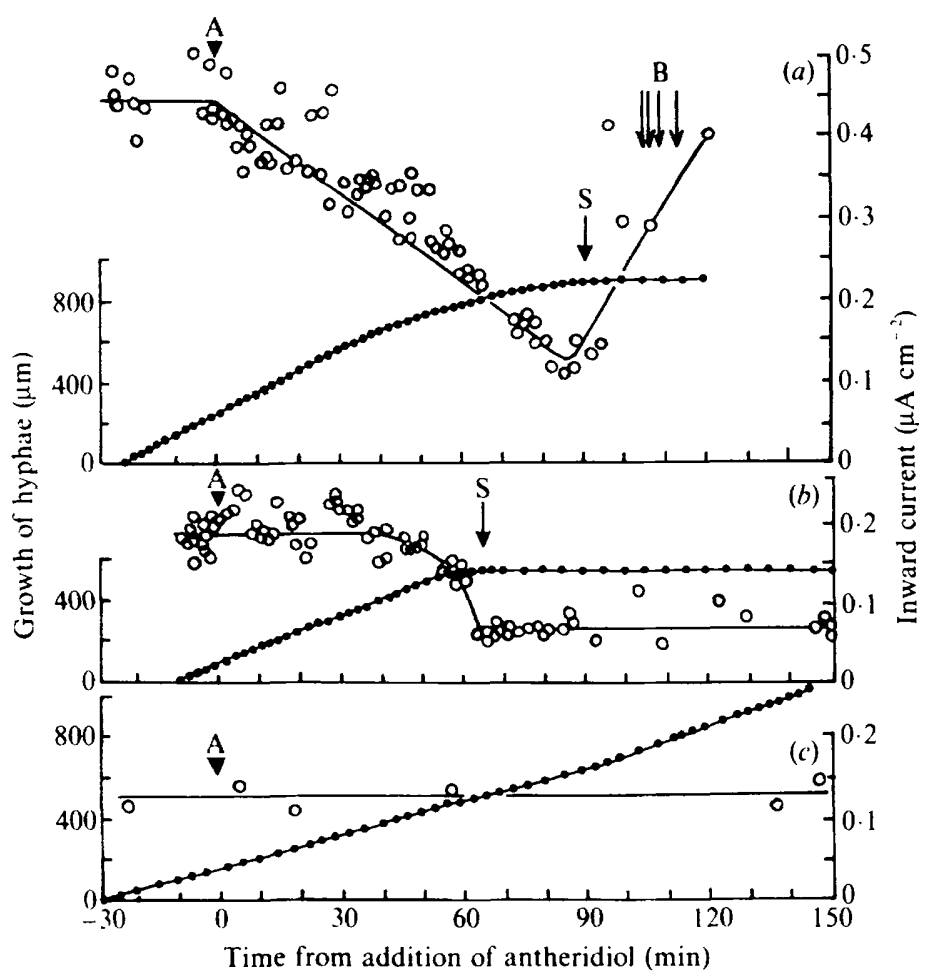

Fig. 1. Growth (O) and apical inward current $(O)$ of three hyphae of $A$. ambisexualis before and after addition of antheridiol (at $\mathbf{A}$, bold arrowhead). Hyphae $(a)$ and $(b)$ were growing into artificial pond water. Hypha (a) stopped growing 92 mins after addition (at S, solid arrow); branches formed 14, 15, 18 and $20 \mathrm{~min}$ later (at B, arrows). Hypha (b) stopped $63 \mathrm{~min}$ after addition (at $S$ ), but unusually no branches formed. Hypha $(c)$ was growing into the nutrient mating medium, and did not stop growing or branch.

Electrical measurements. Electrical currents were measured with a one-dimensional vibrating probe system (Vibrating Probe Co., Davis, Calif., USA) successively at positions closely adjacent to a hypha and at reference positions at least $300 \mu \mathrm{m}$ from the hypha (Kropf et al., 1984; Gow, 1984). The electrode was vibrated at between 200 and $400 \mathrm{~Hz}$ with the vibration amplitude at $30 \mu \mathrm{m}$. Quadrature measurements were made at invervals with the lock-in amplifier $90^{\circ}$ out of phase. These were in no case larger than $5 \%$ of the in-phase signal. The current density was calculated from the electrical field and the medium resistivity (Jaffe \& Nuccitelli, 1974). The resistivity was determined from the conductivity of the bathing media, and did not change during experiments.

Effect of antheridiol. Pure synthetic antheridiol (kindly supplied by Professor T. C. McMorris) was stored in a solution of $100 \mu \mathrm{g} \mathrm{m}^{-1}$ in methanol at $-20^{\circ} \mathrm{C}$. When it was established that the hyphae were growing at a linear extension rate as measured with an eyepiece micrometer, and when steady state current flows had been recorded, antheridiol was added to give an initial nominal concentration of $50 \mathrm{ng} \mathrm{m}{ }^{-1}$. We term this 'nominal' concentration as antheridiol adsorbs onto plastic surfaces (Barksdale, 1963). Control experiments had an equal volume of methanol.

\section{RESULTS}

Hyphae grew out from the block of nutrient agar into the non-nutrient artificial pond water medium at constant extension rates. If treated with antheridiol within the first 2 or $3 \mathrm{~h}$, their extension rates slowed, and they stopped extending between 40 and $100 \mathrm{~min}$ later (Fig. $1 a, b$ ). The first antheridial branches were formed sub-apically between 40 and $100 \mathrm{~min}$ later (Fig. $1 a$ ). The first sign of these were slight bulges, which abruptly herniated and grew as contorted branches (Fig. 2). Very rarely, the stopped hypha did not branch (Fig. $1 b$ ). In the absence of antheridiol, the hyphae grew out for several hours more, and then sporulated. If the agar blocks 


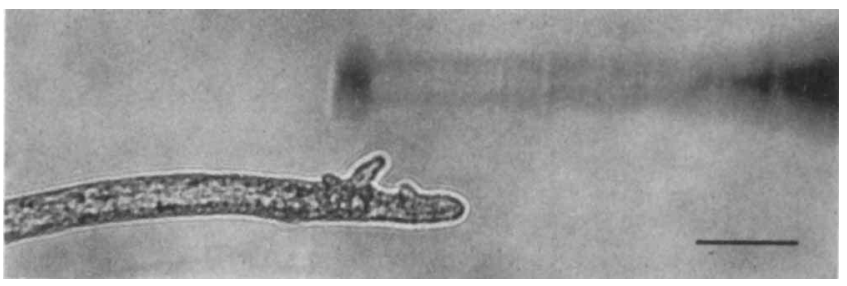

Fig. 2. Antheridial branching of the hypha documented in Fig. 1(a). Four sub-apical branches have formed. The probe is vibrating alongside the hypha. Conditions as described in Fig. 1(a). Bar, $100 \mu \mathrm{m}$.

of Achlya were mounted in liquid nutrient medium, vegetative hyphae grew out without sporulating for several days. These hyphae showed no response when antheridiol was added (Fig. 1c). Control hyphae, i.e. with methanol added, grew normally without branching and eventually sporulated.

Current maps along the hyphae before addition of antheridiol showed the pattern typical of growing hyphae of Achlya, with the inward current of the apical region declining further back along the hypha, eventually giving way to outward current in the distal regions. Following addition of antheridiol, initially this current pattern was maintained, but with the inward apical currents rapidly showing the onset of steady decline to reach about a quarter of their former values by the time they had stopped extending, e.g. from 0.44 to $0.10 \mu \mathrm{A} \mathrm{cm}^{-2}$ (Fig. $1 a$ ). Then new sites of inward current were detected, which increased in magnitude severalfold in a few minutes (Fig. 3). Observation at these sites showed that they became the sites of antheridial branches (Figs 2 and 3). Each new inward current site that was detected was followed by branching. Conversely, no branches were formed in regions not showing such currents or in the occasional hypha not showing any such new inward currents (e.g. that shown in Fig. $1 b$ ). Hyphae growing out into the nutrient mating medium showed no change in current map following addition of antheridiol.

\section{DISCUSSION}

The current maps of hyphae of $A$. ambisexualis E87 growing out into the nutrient or nonnutrient media, showing inward apical and outward distal currents, are similar to those of Achlya debaryana growing from hemp seeds into pond water (Armbruster \& Weisenseel, 1983) and of Achlya bisexualis growing from agar into nutrient medium (Kropf et al., 1983, 1984; Gow et al., 1984; Gow, 1984).

The marked decline in apical current following addition of antheridiol can be compared with the abolition of inward current accompanying cessation of growth caused by $\mathrm{pH}$ change or removal of amino acids (Kropf et al., 1984). A notable difference is that the hyphae stopped by antheridiol still retained a measurable inward apical current.

The observation of a new inward current preceding the formation of an antheridial branch and predicting its site of emergence can be compared with the report of Kropf et al. (1983) of a similar occurrence during vegetative branch formation. The antheridiol-induced response, however, forms a better system for study as, unlike vegetative branching, antheridial branching can be directly controlled.

The lack of electrical or branching response to antheridiol in the presence of nutrients is in accord with the study of Mullins \& Warren (1975) who concluded 'in Achlya that exogenous nutrient conditions favourable for vegetative growth are unfavourable for sexual reproduction'. The cessation of growth of hyphae responding to antheridiol does not seem to have been reported before, but is in accord with the growth arrest of Saccharomyces cerevisiae and Phycomyces blakesleeanus in response to their specific sex pheromones (Betz \& Duntze, 1979; Drinkard et al., 1982). Here, we have only measured this growth arrest as cessation of apical growth rate and it is possible that increase in other growth parameters might continue unabated. 


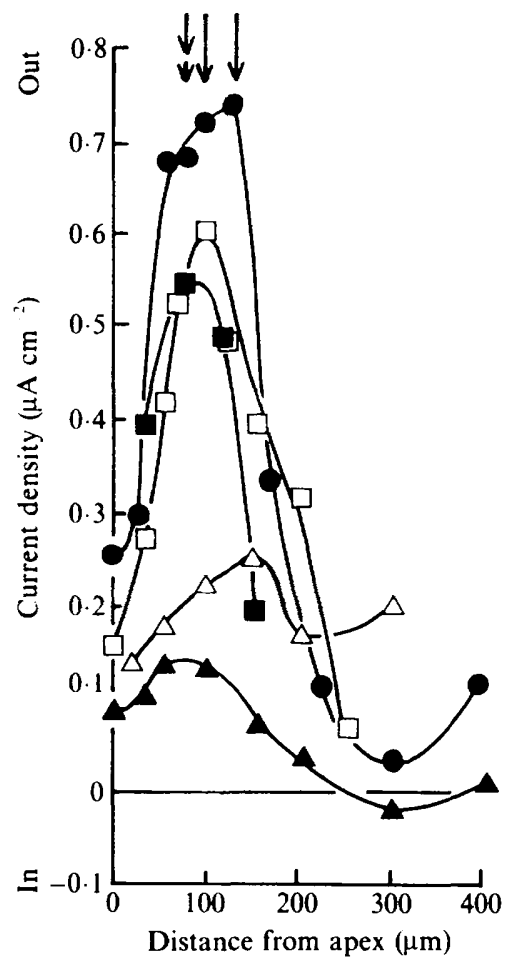

Fig. 3. Longitudinal current maps of the hypha shown in Figs $1(a)$ and 2 at five different times following addition of antheridiol: $78-83 \mathrm{~min}(\Delta), 92-95 \mathrm{~min}(\triangle)$ when the hypha stopped elongating, 96-98 $\mathrm{min}(\square)$, 98-104 $\mathrm{min}(\square)$ and 104-112 $\mathrm{min}(O)$ when the four branches were formed. Positions of branches are indicated by arrows.

The biochemical responses to antheridiol outlined in the Introduction (Horgen, 1981; Gooday, 1983) are observed from about 30 min after exposure of Achlya to antheridiol and there is evidence for a cytosolic antheridiol-binding protein with properties similar to those of vertebrate steroid receptors (Riehl et al., 1984). However, the speed of response of the apical current to the addition of antheridiol shown in Fig. $1(a)$ suggests that in addition there may be surface receptors for this sterol.

We thank Professor T. C. McMorris for A. ambisexualis E87 and synthetic antheridiol, and the Science and Engineering Research Council, the Society for General Microbiology and the University of Aberdeen for Grants for purchase of equipment.

\section{REFERENCES}

ARMbruster, B. L. \& WeisenSEel, M. H. (1983). Ionic currents traverse growing hyphae and sporangia of the mycelial water mold Achlya debaryana. Protoplasma 115, 65-69.

BARKSDALE, A. W. (1963). The uptake of exogenous hormone A by certain strains of Achlya. Mycologia 55, 627-632.

Barksdale, A. W., McMorris, T. W., Seshadri, R., Arunachalam, T., Edwards, J. A., Sundeen, J. \& GreEN, D. M. (1974). Response of Achlya ambisexualis E87 to the hormone antheridiol and certain other steroids. Journal of General Microbiology 82, 295-299.
Betz, R. \& Duntze, W. (1979). Purification and partial characterisation of $\alpha$-factor, a mating hormone produced by mating-type- $a$ cells from Saccharomyces cerevisiae. European Journal of Biochemistry 95, 469-475.

BRUNT, S. A. \& SIL VER, J. C. (1986). Steroid hormoneinduced changes in secreted proteins in the filamentous fungus Achlya. Experimental Cell Research 163, 22-34.

Drinkard, L. C., Nelson, S. E. \& Sutter, R. P. (1982). Growth arrest: a prerequisite for sexual development in Phycomyces blakesleeanus. Experimental Mycology 6, 52-59. 
GoODAy, G. W. (1983). Hormones and sexuality in fungi. In Secondary Metabolism and Differentiation in Fungi, pp. 239-266. Edited by J. W. Bennett \& A. Ciegler. New York: Marcel Dekker.

Gow, N. A. R. (1984). Transhyphal electrical currents in fungi. Journal of General Microbiology 130, 33133318.

Gow, N. A. R., KROPF, D. L. \& HAROLD, F. M. (1984). Growing hyphae of Achlya bisexualis generate a longitudinal $\mathrm{pH}$ gradient in the surrounding medium. Journal of General Microbiology 130, 29672974.

HoRGEN, P. A. (1981). The role of the steroid sex pheromone antheridiol in controlling the development of male sex organs in the water mold Achlya. In Sexual Interactions in Eukaryotic Microbes, pp. 179188. Edited by D. H. O’Day \& P. A. Horgen. New York: Academic Press.

JAFFE, L. F. \& NuCCITELLI, R. J. (1974). An ultrasensitive vibrating probe for measuring steady extracellular currents. Journal of Cell Biology 63, 614-628.

KROPF, D. L. (1986). Electrophysiological properties of Achlya hyphae: ionic currents studied by intracellular potential recording. Journal of Cell Biology 102, 1209-1216.

Kropf, D. L., Lupa, M. D. A., Caldwell, J. H. \& HAROLd, F. M. (1983). Cell polarity: endogenous ion currents precede and predict branching in the water mold Achlya. Science 220, 1385-1387.
Kropf, D. L., Caldwell, J. H., Gow, N. A. R. \& HaROLD, F. M. (1984). Transcellular ion currents in the water mold Achlya. Journal of Cell Biology 99, 486-496.

MCMORRIS, T. C. (1978). Antheridiol and the oogoniols, steroid hormones which control sexual reproduction in Achlya. Philosophical Transactions of Royal Society of London 284, 459-470.

Mullins, J. T. \& WarReN, C. O. (1975). Nutrition and sexual reproduction in the water mold Achlya. American Journal of Botany 62, 770-774.

Musgrave, A. \& Nieuwentuis, D. (1975). Metabolism of radioactive antheridiol by Achlya species. Archives of Microbiology 105, 313-317.

Riehl, R. M., TOFT, D. O., MEyer, M. D., Carlson, G. L. \& McMorris, T. C. (1984). Detection of a pheromone-binding protein in the aquatic fungus Achlya ambisexualis. Experimental Cell Research 153, 545-549.

Silver, J. C. \& Horgen, P. A. (1974). Hormonal regulation of presumptive mRNA in the fungus Achlya ambisexualis. Nature, London 249, 252-254.

Thomas, D. S. \& Mullins, J. T. (1969). Cellulase induction and wall extension in the water mold Achlya ambisexualis. Physiologia plantarum 22, 347353.

Timberlake, W. (1976). Alterations in RNA and protein synthesis associated with steroid hormoneinduced sexual morphogenesis in the water mold Achlya. Developmental Biology 51, 202-214. 